УДК 549 (234.85)

\title{
МОРФОЛОГИЧЕСКИЕ ОСОБЕННОСТИ ЦИРКОНОВ ИЗ МЕТАМОРФИЧЕСКИХ ПОРОД И ГРАНИТОИДОВ ТИМАНО-УРАЛЬСКОГО РЕГИОНА
}

\author{
Ю. И. Пыстина, А. М. Пыстин \\ Институт геологии Коми НЦ УрО РАН, г. Сыктывкар \\ Поступила в редакцию 7 июня 2018 г.
}

\begin{abstract}
Аннотация: на примере полиметаморфических комплексов Тимано-Уральского региона показано, что округленные цирконы (типа «футбольного мяча») кристаллизуются в породах, испытавших экстремальные условия метаморфизма (гранулитах и эклогитах). Призматические иирконы, наиболее характерны для мигматизированных метаморфических пород. Цирконы ицирконовые сростки сложной формы (типа «цветной капусты») образуются преимущественно в условиях относительно низких ступеней амфиболитовой фаџии при отсутствии или слабом проявлении прочессов мигматизаџии. Выполнен генерационный анализ цирконов из гранитоидов северной части Приполярного Урала. Показано, что цирконы из пород разных гранитоидных комплексов, занимающих разную геологическую позищию и имеющих разный изотопный возраст, отличаются по набору морфотипов и их количественным соотночениям.
\end{abstract}

Ключевые слова: Тимано-Уральский регион, иирконы, полиметаморфические комплексы, гранитоиды, типоморфизм.

\section{MORPHOLOGICAL FEATURES OF ZIRCONS FROM METAMORPHIC ROCKS AND GRANITOIDS OF THE TIMAN-URAL REGION}

\begin{abstract}
Timan-Ural region it is shown that rounded zircons (such as "soccer-ball») crystallize in rocks that have experienced extreme conditions of metamorphism (granulites and eclogites). Prismatic zircons are the most characteristic for the migmatized metamorphic rocks. Zircons and zircon joints of complex shape (such as "cauliflower») are formed mainly in conditions of relatively low levels of amphibolite facies in the absence or weak manifestation of the processes of migmatization. The generation analysis of zircons from granitoids of the Northern part of the Subpolar. Urals is performed. It is shown that zircons from rocks of different granitoid complexes, occupying different geological positions and having different isotopic ages, differ in the set of morphotypes and their quantitative ratios.
\end{abstract}

Key words: Timan-Ural region, zircons, polymetamorphic complexes, granitoids, typomorphism.

\section{Введение}

Циркон один из минералов, наиболее широко используемых для реконструкции условий образования вмещающих его магматических и метаморфических пород. Благодаря своей физико-химической устойчивости он сохраняется даже при достаточно высоких температурах и давлениях, при этом последовательно развивающиеся геологические процессы вносят определенные изменения в состав и морфологию существующих кристаллов циркона. Именно поэтому, минерал часто имеет большое разнообразие в морфологическом плане и сложное внутреннее строение. Но именно это и позволяет использовать циркон, как индикатор геологических процессов. Кроме того, благодаря наличию примеси U в минерале при сравнительно высокой температуре закрытия $\mathrm{U}-\mathrm{Pb}$ изотопной системы (около $900^{\circ} \mathrm{C}$ ), циркон является одним из самых надежных геохронометров.
В статье дается краткий обзор публикаций, посвященных теоретическому обоснованию морфологии циркона и эмпирическим наблюдениям за морфологическими особенностями этого минерала из пород метаморфического и магматического генезиса. Приводятся также результаты изучения морфологии циркона из метаморфических и гранитоидных комплексов некоторых районов Тимано-Уральского региона.

\section{Теоретическое обоснование морфологии} циркона и эмпирические наблюдения

Кристаллические формы циркона представлены гранями $\{011\},\{100\},\{110\},\{211\},\{031\},\{112\}$ и т.д. Теоретическая форма роста циркона, выведенная из кристаллической структуры, предсказана с использованием теории периодических цепей связей (ПЦС) [1, 2]

Согласно ПЦС-теории [1] адсорбция катионов на 
грани $\{011\}$ изменяет относительные поверхностные энергии возможных структур и это, в свою очередь, изменяет механизм и скорость роста. Если адсорбция делает поверхностные энергии двух возможных структур равными, рост может происходить путем приложения половины слоя $\{022\}$, который растет приблизительно с удвоенной скоростью по сравнению с ростом целых элементарных слоев $\{011\}$.

Теоретические формы обычно не реализуются в естественных условиях роста, но они служат отправной точкой для оценки влияния внешних факторов.

Р. Каруба с соавторами [3] описали рост кристаллов циркона при использовании в качестве зародышей естественных цирконов в сульфатных гидротермальных растворах. Они заметили, что кристаллизация формы $\{011\}$ медленнее по сравнению с $\{100\}$. В результате экспериментальная форма роста показывает дипирамидальный габитус с $\{011\}$ даже тогда, когда материал зародышей был призматическим. По их мнению, скорость роста $\{011\}$ уменьшается в ходе кристаллизации с уменьшением $\mathrm{pH}$ среды, что ведет к большему количеству дипирамидальных форм.

Наличие незначительной коррозии на кристаллической поверхности достаточно, чтобы разрушить адсорбционный слой и увеличить скорость роста граней, пока адсорбционный слой не восстановлен [4]. Так как смежные кристаллические формы $(\{011\},\{100\},\{110\})$ сильно различаются по скоростям роста, размеры $\{121\}$ и $\{031\}$ в форме кристаллов преимущественно определяются геометрическими отношениями. Быстрый рост $\{100\}$ обусловливает наличие грани $\{031\}$ и увеличивает ее размер, быстрые интервалы роста $\{011\}$ увеличивают размер смежных $\{121\}$ граней [4].

Систематические исследования типологии циркона привели к созданию широко используемой « Пюпин-диаграммы», в которой кристаллы циркона классифицированы согласно относительному развитию $\{100\},\{110\}$ призматических форм и $\{211\}$, $\{101\}$ пирамидальных кристаллических форм [5]. Например, зерна циркона из относительно сухих щелочных и толеитовых вулканических пород имеют тенденцию приобретать $\{100\}$ и $\{101\}$ формы, цирконы из гранитов от глинозёмистого до известково-щелочного рядов показывают различные комбинации форм с явным присутствием $\{211\}$, а из «водных» гранитов и пегматитов имеют тенденцию приобретать в качестве доминирующих формы $\{110\}$ и $\{101\}$. Дж. Пюпин [5] связал относительное развитие призматических граней, главным образом, с температурой кристаллизации, тогда как пирамидальные грани, по его мнению, были связаны с химическими факторами, и предположил, что типологические параметры популяции циркона могут использоваться для описания развития магматической системы. Г. Вавра, Бенисек и Ф. Фингер $[6,7]$ показали, что состав среды оказывает существенное влияние на развитие призматических поверхностей в цирконе.

У природных цирконов магматического генезиса форма кристалла проявляется главным образом приз- мой $\{100\}$ и дипирамидой $\{011\}$. Иногда, однако, встречаются цирконы призматического габитуса с $\{110\}$ призмами и с $\{011\}$ дипирамидами. В очень редких случаях естественный циркон имеет дипирамидальный облик с $\{011\}$ призмами. В мафических и ненасыщенных щелочных породах встречаются скелетные кристаллы циркона (рис. 1.1-1.2), которые характеризуются развитием вершин и граней, окружающих пустое пространство [8]. Сопоставимый тип циркона, показывающий полые призмы или другие не полностью выращенные кристаллы, обнаружен в базальтовом андезите. По мнению Дж. Хунека и П. Росмана [9] он указывает на кристаллизацию минерала в пневматолитовую фазу (рис. 1.3). Во многих магмах насыщение цирконием происходит на ранних стадиях и, таким образом, циркон осаждается одновременно с большинством других минералов. В некоторых случаях кристаллизация циркона происходит позже, например, в высокофракционируемой магме, в изолированных очагах магмы, или во включениях в других минералах. Такие цирконы обычно имеют только частично развитые кристаллические поверхности (рис. $1.1)$, они характерны для габброидов $[10,11]$.

В других случаях частичная или полная кристаллизация циркона может происходить, когда магма пересыщена цирконием. Такая магма не способна полностью растворить ассимилируемый циркон и ранее выросший магматический циркон часто становятся затравкой. Ксенокристаллы циркона могут иметь как гладкие зерна, свободные от любого нароста (рис. 1.4-1.6), так и полностью покрытые новообразованной оболочкой (рис. 1.7-1.15). В некоторых породах можно наблюдать ксенокристаллы циркона без нароста, ксенокристаллы с ядрами и новообразованными оболочками и полностью новообразованные магматические цирконы (рис. 1.21-1.22). Кроме того, новообразованные кристаллы циркона, в свою очередь, часто обнаруживают множество стадий роста и окисления. Все эти особенности могут быть связаны со сложной эволюцией состава магмы.

Метаморфически выращенные, или метаморфически измененные кристаллы циркона, характеризуются либо округленными и сильно изрезанными формами (рис. 1.16-1.20), либо эвгедральными формами. Последние типичны для кристаллических слюдяных сланцев и мигматитов. В первом случае, развитие кристаллических поверхностей было, по-видимому, облегчено присутствием водных или содержащих углерод жидкостей, во втором случае, циркон, вероятно, вырос в контакте с фазой расплава, и, следовательно, строго говоря, является скорее не метаморфическим, а магматическим.

Округленный метаморфический циркон встречается в разных модификациях. В некоторых породах кристаллы циркона обнаруживают лишь небольшое округление граней, тогда как в других цирконы представлены округлыми зернами с мультифасеточным множестом внешних граней (рис. 1.19-1.20). Они известны как цирконы типа «футбольного мяча» [12] 


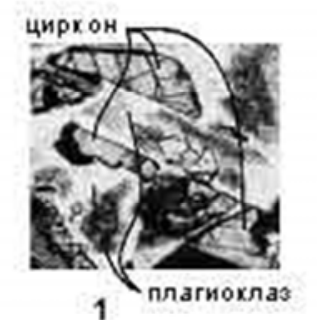

1

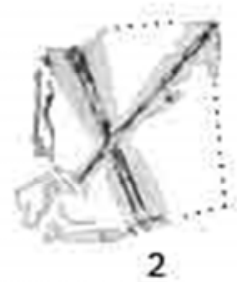

2
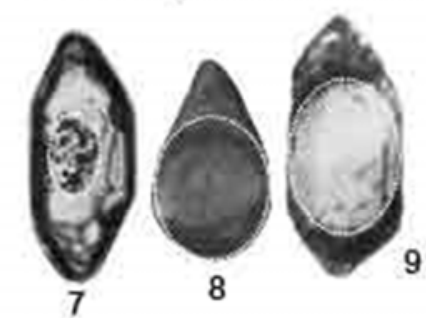

9

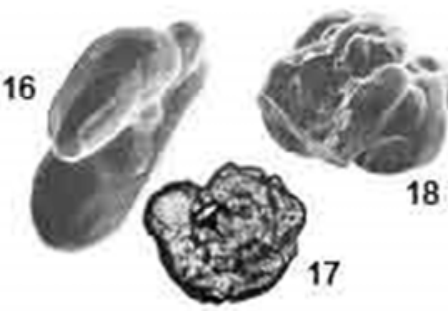

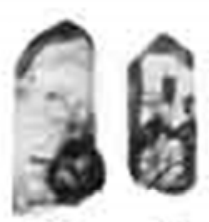

1011

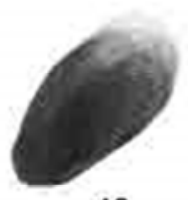

19

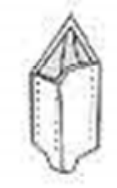

3

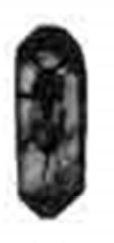

12

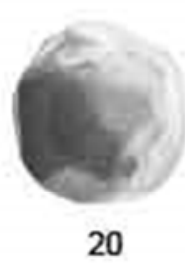

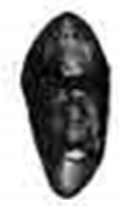

4
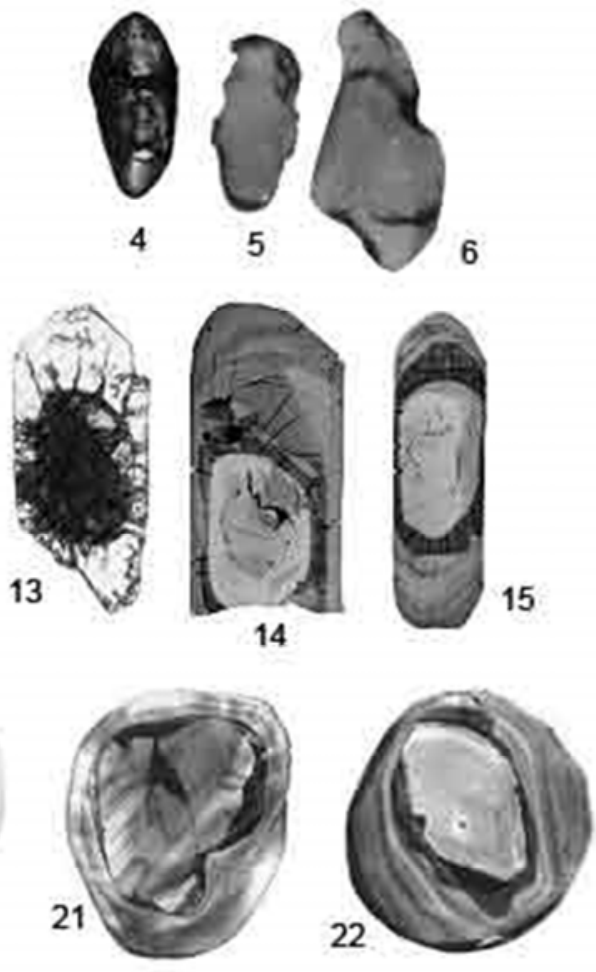

Puc.1. Вариации морфологии цирконов из магматических и метаморфических пород по опубликованным данным [8].

и наиболее характерны для пород, претерпевших экстремальные ( ультравысокотемпературные или ультравысокобарические) условия метаморфизма. При этом, зерно может состоять в значительной степени из перекристаллизованного первоначального циркона или, наоборот, полностью новообразованного метаморфического циркона.

Некоторые метаморфические породы содержат зерна циркона сложной кристаллографической формы. Они в публикациях известны, как цирконы типа «цветной капусты» (рис. 1.17-1.18). В одних случаях форма этих зерен может отражать поглощение при росте минерала фрагментированных цирконов, в других, - они, вероятно, представляют собой метаморфически выращенный поликристаллический циркон. По мнению Дж. Пиюкета и его коллег [13] такие цирконы характерны для метаморфических пород основного состава. Тем не менее, как будет показано ниже, подобные цирконы встречаются также и в метаморфитах кислого ряда.

Разнообразие метаморфических цирконов, по мнению многих исследователей $[14,15,16,17]$ отражает вариации в физико-химических условиях и продолжительности каждого метаморфического события и вызвано модификациями существовавших ранее структур и/или ростом нового циркона. Относительно слабо подверженные изменениям зерна циркона могут частично наследовать остатки первоначального зонирования роста, лишь частично измененные метаморфизмом, и практически сохранять строение последней магматической перекристаллизации. Очень важно, что остаются реликты первичных строений (зонирование роста) в пределах областей рекристализации. Эти реликты называют «побочным строением» и они ответственны за «смешанные» изотопические возрасты и распространенность рассеянных элементов между росто-зонированными и полностью рекристаллизованными областями кристаллов цирконов.

\section{Морфологические особенности цирконов из мета- морфических пород Тимано-Уральского региона}

Многолетние исследования цирконов из гнейсов и кристаллических сланцев полиметаморфических комплексов Тимано-Уральского региона (рис. 2) [18, 19, 20 и др.] убеждают нас в том, что в метаморфических породах цирконы действительно отличаются большим разнообразием форм и сложностью строения. В них встречаются как аллотигенные, так и аутигенные цирконы.

К алотигенным уверено относятся только окатанные (терригенные) цирконы. Они отличаются округлой или элипсовидной формой и имеют шероховатую поверхность (рис. 3.1). Минерал может быть бесцветным или окрашенным в розовые тона, вплоть до темно-розового.

Среди аутигенных цирконов, кристаллизация которых связана с метаморфическим изменением пород, наибольшим распространением пользуются три морфологические разновидности (три морфотипа) [21]. Одна из распространенных разновидностей метаморфогенных цирконов в изученных нами породах представлена округленными зернами (типа «футбольного мяча») (рис.3.2-3.7). При этом, как уже отмечалось выше, кристаллы циркона могут быть лишь слегка 


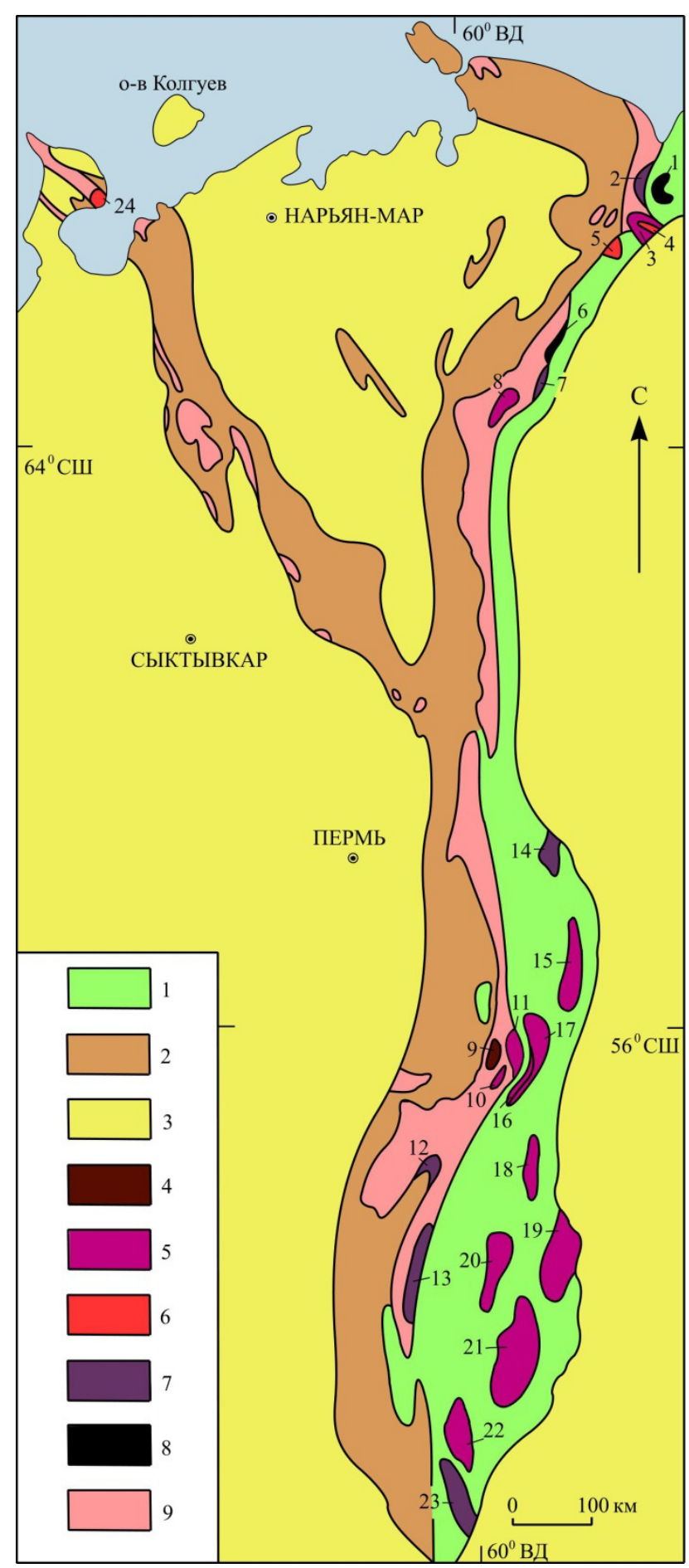

Puc. 2. Схема расположения полиметаморфических комплексов Тимано-Уральского региона: $1-2$ - палеозойские формации: 1 - палеоокеанические; 2 - палеоконтинентальные; 3 - осадочный чехол Европейской платформы; 4-7 - нижнедокембрийские (?) полиметаморфические комплексы: 4 - гнейсогранулитовые, 5 - гнейсо-мигматитовые, 6 - кристаллосланцевые, 7 - эклогит-гнейсовые и эклогит-сланцевые; 8 - гранулитметабазитовые; 9 - верхнепротерозойские образования, преимущественно претерпевшие зеленосланцевый метаморфизм.

Полиметаморфические комплексы: 1 - малыкский, 2 - марункеуский, 3 - ханмейхойский, 4 - париквасьшорский, 5 хараматалоуский, 6 - хордъюский, 7 - неркаюский, 8 - няртинский, 9 - тараташский, 10 - александровский, 11 - уфалейский, 12 - белорецкий, 13 - максютовский, 14 - салдинский, 15 - мурзинско-адуйский, 16 -селянкинский, 17 - сысертскоильменогорский, 18 - кочкарский, 19 - мариинский, 20 - адамовский, 21 - текельдытауский, 22 - кайрактинский, 23 - талдыкский, 24 - микулкинский.

округлыми, сохраняя дипирамидально- призматический габитус, обусловленный развитием граней $\{100\},\{110\}$ и дитетрагональной дипирамидой $\{311\}$ или дипирамидой $\{331\}$ (рис. 3.2). В других случаях циркон приобретает полностью округлую, часто изометричную (шаровидную) форму (рис. 3.3). Поверхность граней гладкая, блестящая. Внутреннее строение таких цирконов сравнительно однородное, но встречаются кристаллы с ядрами более древнего циркона (рис. 3.5-3.7). Новообразованная оболочка вокруг них характеризуется небольшим содержанием включений. Мощность ее может быть значительной, особенно вблизи вершин кристаллов. На Урале такие цирконы впервые были описаны А. А. Краснобаевым [22] в гранулитах тараташского гнейсо-гранулитового комплекса Южного Урала и выделены им в «гранулитовый» тип. Можно согласиться сА. А. Краснобаевым, что округлая форма зерен циркона обусловлена их ростом «... в жестких Р-Т условиях ... метаморфизма, когда полигональная форма зерен любых минералов, в том числе и цирконов, выступающих в роли затравок, неустойчива, поскольку испытывает неравномерные механические и температурные напряжения. Как вновь возникшие, так и реликтовые цирконы обязаны расти таким образом, чтобы свести к минимуму напряженность границ и приобрести равновесную изометричную форму» [22, стр. 49].Поскольку такой циркон характерен не только для гранулитов, но и для эклогитов, предпочтительнее выделять его как циркон типа «футбольного мяча». Отметим, что кроме гранулит- и эклогитсодержащих метаморфических комплексов, подобный циркон в небольших количествах установлен в метаморфитах гнейсо- мигматитовых комплексов Урала (александровском, селянкинском, няртинском, ханмейхойском и др.), сложенных породами амфиболитовой фации. Это дает основание предполагать, что породы изначально были метаморфизованы в условиях гранулитовой фации. Эта точка зрения подтверждается находками реликтов гранулитов (в селянкинском комплексе) и составом реликтовых породообразующих метаморфических минералов (в александровском и няртинском комплексах).

Другая разновидность цирконов, широко представленная в гнейсах и кристаллических сланцах, имеет вид прозрачных и светлоокрашенных зерен призматического габитуса (рис. 3.8-3.10). В минерале развиты грани $\{100\},\{110\},\{112\},\{113\}$. Присутствуют $\{331\}$ или другая острая дипирамида. Комбинация небольшой по площади острой дипирамиды и хорошо выраженной тупой обуславливает округлый облик головки кристалла. В площадном отношении преобладают грани призм. Внутреннее строение отличается многозональностью. Расположение зон относительно друг друга может быть симметричным и 

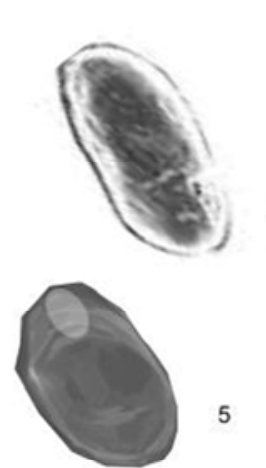

1
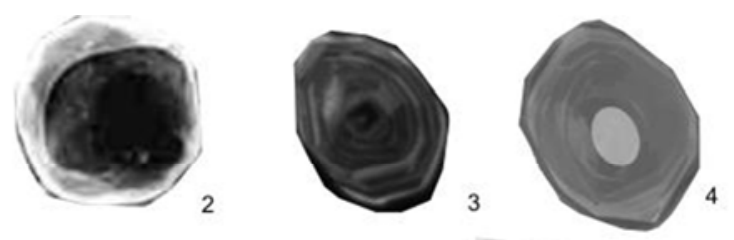

5

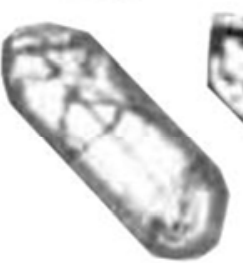

9
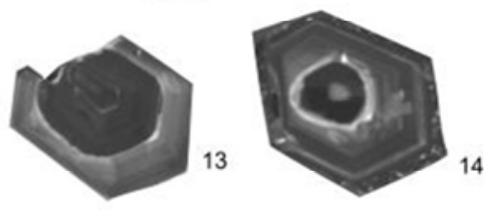
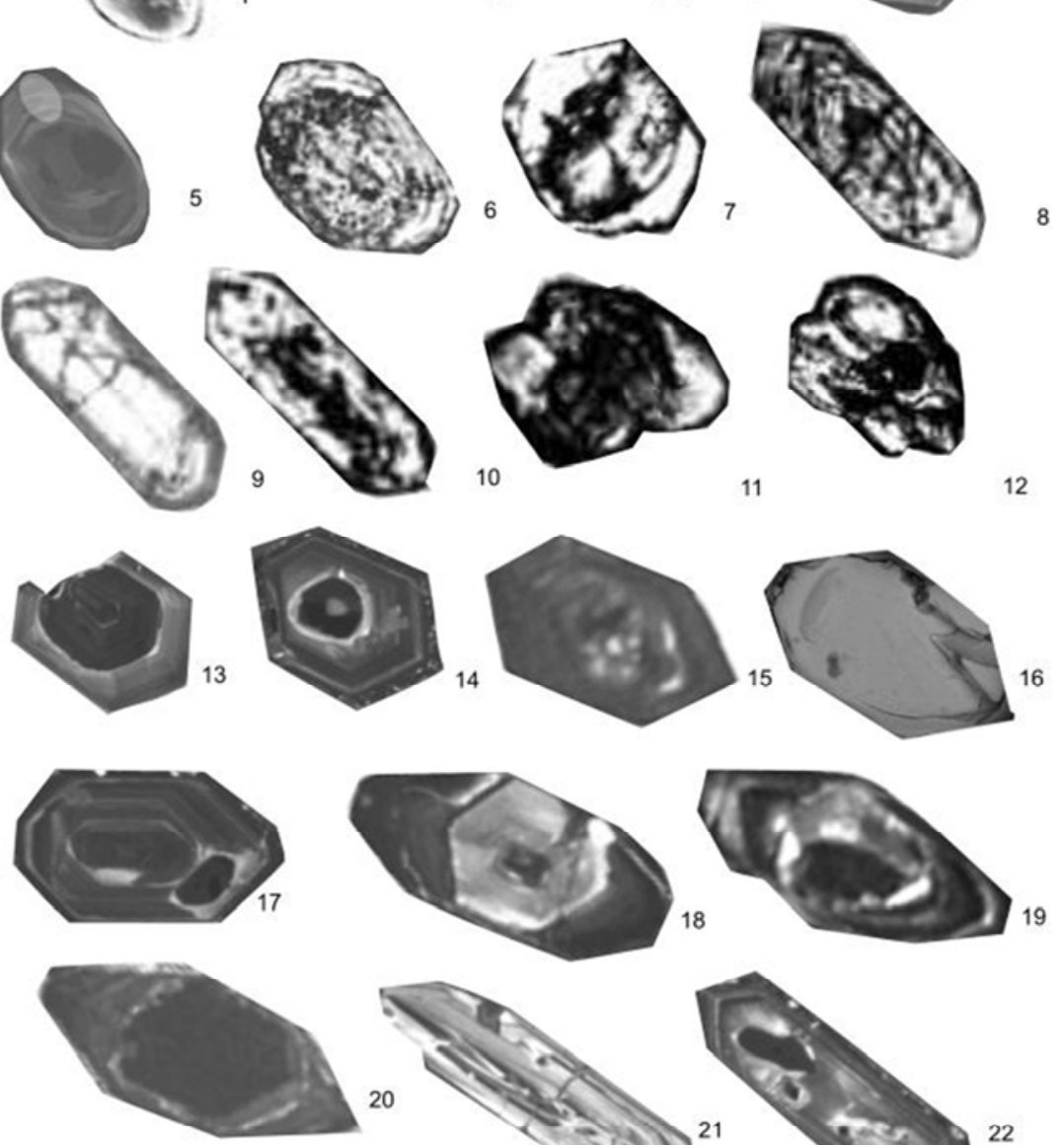

20
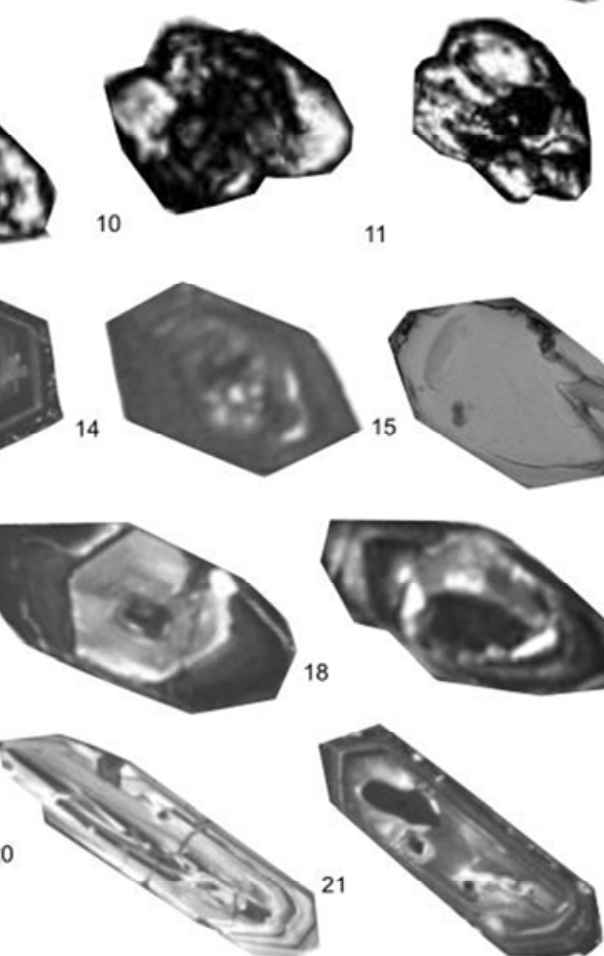

11

12
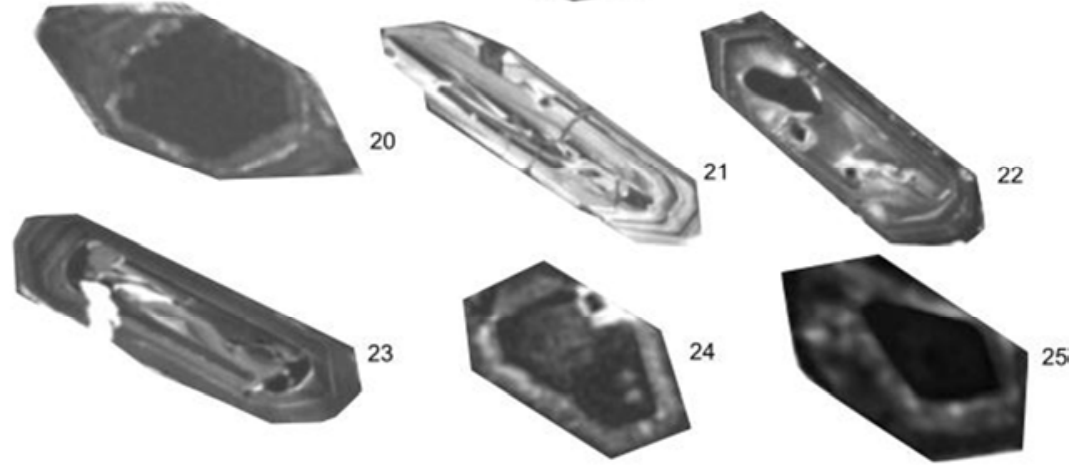

Рuc. 3. Вариации морфологии цирконов из пород полиметаморфических комплексов Урала.

несимметричным, центральная часть кристалла часто затемнена и имеет вид «псевдоядер». Среди включений распространены твердые и газово-жидкие; многие кристаллы содержат полости, выходящие на поверхность. Форма включений различна: это игловидные и изометричные образования, тонкие трубочки, канальчики. Расположение их хаотично. В отдельных кристаллах наблюдается приуроченность включений к границам зон, мелким трещинкам. На Урале подобный циркон описан А. А. Краснобаевым [22] в биотитовых, биотит-амфиболитовых гнейсах и мигматитах ильменогорского комплекса Южного Урала и выделен им в «мигматитовый» тип. Как было отмечено выше, призматическая форма циркона, вероятно, обусловлена тем, что минерал вырос в контакте с фазой расплава. От циркона типичного магматического ге- незиса его отличает более сложное внутреннее строение (псевдоядра, асимметричность зон, полости и др.), что, скорее всего, является результатом роста минерала при меняющихся условиях среды (состав и наличие или отсутствие магмы, $\mathrm{pH}$, и др.). Таким образом, циркон «мигматитового» типа несет в себе черты как магматического, так и метаморфического минерала, т.е. минерала смешанного генезиса. Поэтому, на наш взгляд, термин «мигматитовый» для данного морфологического типа является удачным. Этот тип циркона является наиболее распространенным в полиметаморфических образованиях Урала.

Более ограниченное распространение в метаморфических породах имеют цирконовые сростки сложной формы (типа «цветной капусты»). Однако в некоторых метаморфических комплексах они домини- 
руют среди других морфологических разновидностей цирконов. Относительно высокое содержание таких цирконов нами установлено в породах париквасьшорского комплекса Полярного Урала и микулкинского комплекса полуострова Канин. Циркон представлен бесцветными или бледно-окрашенными зернами неправильной формы (рис. 3.11-3.12.). При увеличении видно, что кристаллы представляют собой сростки двух или более индивидов. Размер зерен $0,10-0,25$ мм. Поверхность граней гладкая, блестящая. Внутреннее строение кристаллов характеризуется наличием ядер, образованных более древними цирконами. Отмечаются твердые и газово-жидкие включения, расположенные хаотично. Причина возникновения столь замысловатых форм цирконов, возможно, заключается в отсутствии силикатного расплава и дефицита флюидов. Не случайно, как заметили Дж. Пиюкет и его коллеги [13], такие формы характерны для цирконов из метаморфических пород мафитового состава, для которых, как известно, выше температурный порог мигматизации. Нами они установлены также в метаморфитах кислого состава (кристал- лических сланцах и кварцитах), но только в тех комплексах, где условия метаморфизма не превышали низких ступеней амфиболитовой фации и, соответственно, не сопровождались процессами мигматизации.

\section{Морфологические особенности цирконов из гранитоидов Приполярного Урала}

Морфологические особенности цирконов из гранитоидов рассмотрены нами на примере Приполярного Урала, где магматическими образованиями кислого ряда сложено более двадцати массивов, объединенных в несколько разновозрастных комплексов.

Проведен сравнительный анализ цирконов из гранитоидов, относящихся к трем комплексам (рис. 4): николайшорскому $\left(\mathrm{PR}_{1}\right)$, представленному одноименным гранито-гнейсовым массивом, кожимскому $\left(\mathrm{RF}_{2-}\right.$ 3), представителем которого на изученной территории является Кожимский массив и сальнеро-маньхамбовскому $\left(\mathrm{RF}_{3}-\mathrm{C}_{1}\right)$, объединяющему несколько интрузивных массивов, из которых для целей нашего исследования выбраны Бадъяюский и Яротский.

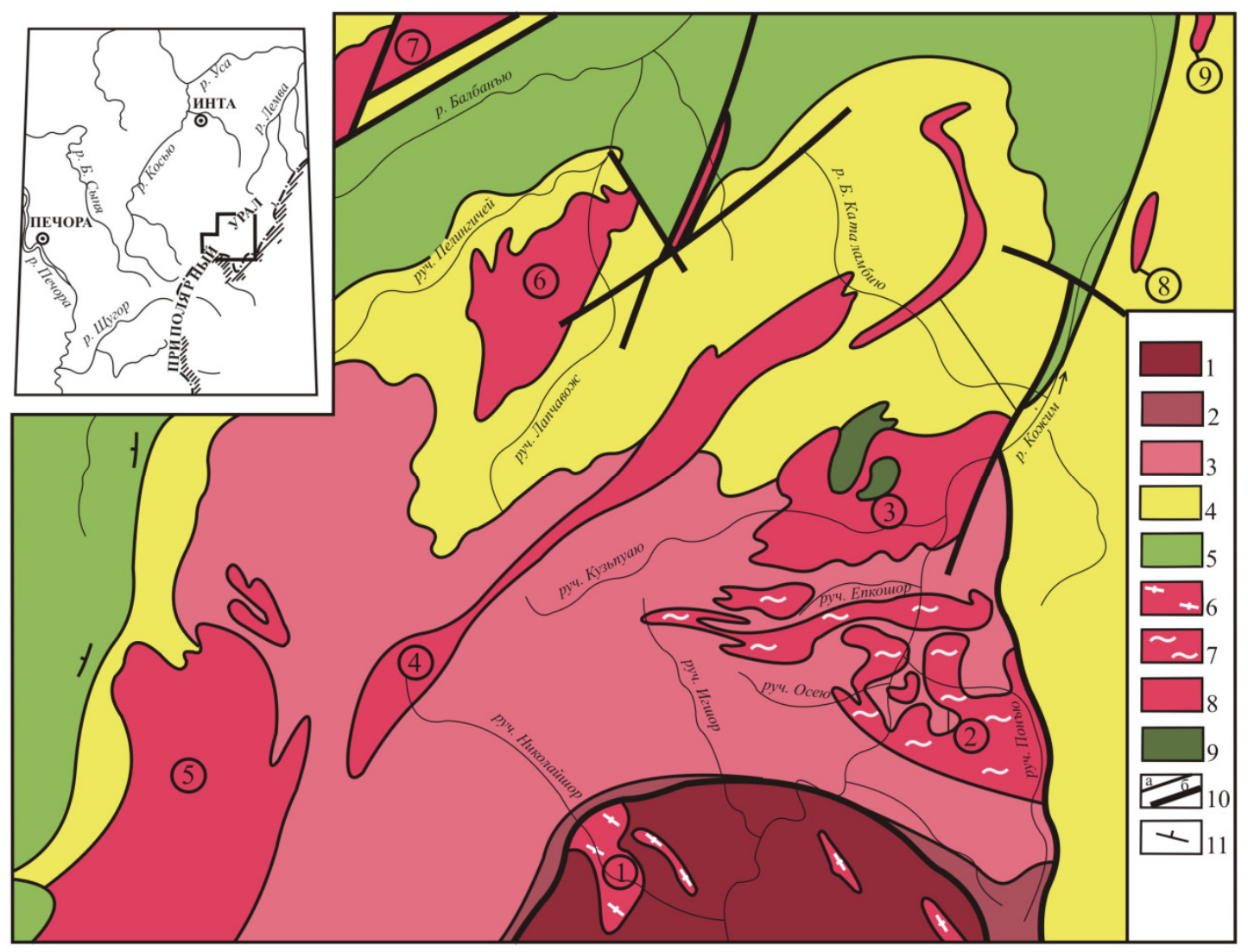

Puc. 4. Схема геологического строения северной части Приполярного Урала: 1 - няртинский гнейсовый комплекс (PR1): биотитовые и двуслюдяные гнейсы с простоями амфиболитов; 2 - щокурьинская свита (RF1?): известковистые кристаллические сланцы, мраморы, кварциты, амфиболовые сланцы; 3 - пуйвинская свита (RF2): слюдяно- кварцевые сланцы, зеленые ортосланцы, метапорфиры, кварциты; 4 - хобеинская (RF3), мороинская (RF3) и саблегорская (RF3-V) свиты нерасчлененные: слюдяно- кварцевые сланцы, порфиры, порфириты, прослои мраморов и кварцитов; 5 - нижнепалеозойские террегенно- карбонатные отложения; 6 - гранито-гнейсы Николайшорского массива (PR1); 7 - граниты Кожимского массива (RF2-3); 8 - граниты массивов сальнероманьхамбовского комплекса (V-C1); 9 - массивы габбро (RF3-V1); 10 - геологические границы: $a$ - стратиграфические и магматические, $\sigma$ - тектонические; 11 - элементы залегания плоскостных структур.

Массивы (цифры в кружочках): 1 - Николайшорский; 2 - Кожимский; 3 - Кузьпуаюский; 4 - Хаталамба-Лапчинский; 5 - Народинский; 6 - Лапчавожский; 7 - Малдынырский; 8 - Яротский; 9 - Бадьяюский. 
Цирконы из пород разных гранитоидных комплексов, занимающих разную геологическую позицию и различающихся по изотопному возрасту, отличаются по набору морфотипов и их количественным соотношениям [23, 24, 25]. Суммарно они представляют все основные морфологические типы цирконов по И. В. Носыреву [14]: цирконовый, гиацинтовый, копьевидный, торпедовидный и циртолитовый ( рис.3.133.25.). Кроме того, в гранитах могут присутствовать детритовые цирконы. Цирконовыци морфологический тип составляют прозрачные и полупрозрачные бледно- окрашенные, реже темно коричневые цирконы коротко-призматического габитуса. Размер кристаллов 100-250 мкм, коэффициент удлинения 1,2-2. Облик, обусловленный развитием граней (100), (111), (110), идиоморфный или субидиоморфный. Соотношение относительных площадей призмы и дипирамиды показывает явное преобладание призматического пояса. Поверхность граней часто трещиноватая, при увеличении обнаруживается неравномерный рельеф. Внутреннее строение кристаллов, как правило, многозональное. Расположение зон относительно друг друга симметричное. В отдельных кристаллах отмечаются округлые ядра, и практически во всех кристаллах присутствуют регенерационные каймы (рис. 3.133.14). Среди включений отмечаются кварц, эпидот, апатит. Включения расположены хаотично. Гиацинтовый морфологический тип цирконов представлен полупрозрачными реже прозрачными светлоокрашенными кристаллами дипирамидально-призматического или короткопризматического габитуса. Размер зерен 200-500 мкм, коэффициент удлинения 1,5-2 Облик кристаллов идиоморфный, обусловлен развитием граней (100), (111), (110), (131), (331). Соотношение площадей граней призм и дипирамид $-1: 2$. Поверхность граней гладкая, блестящая. Внутреннее строение кристаллов часто многозональное, зоны обычно повторяют контур кристалла, но часто отмечается смена граней с тупой дипирамиды на более острую и наоборот (рис. 1.15-3.16). Среди включений отмечаются кварц и биотит. Копьевидный морфологический тип цирконов образуют прозрачные бледно-окрашенные кристаллы дипирамидально-призматического и призматически-дипирамидального габитуса. Размер зерен 200-450 мкм, коэффициент удлинения 2-4. Облик кристаллов идиоморфный, обусловленый развитием граней (100), (110), (131), (311). Соотношение площадей граней призм и дипирамид $-2: 3$. Поверхность граней гладкая, блестящая. Внутреннее строе- ние кристаллов часто многозональное. Расположение зон относительно друг друга может быть симметричным и несимметричным, отмечаются кристаллы с округлыми ядрами, а также ядрами, представленными неправильными сростками реликтового циркона ( рис. 3.17-3.20). В отдельных случаях можно наблюдать, как менялся облик кристалла от цирконового до дипирамидально- призматического - копьевидного. Встречаются включения апатита, кварца, слюды, реже монацита, ксенотима. Характерной особенностью цирконов этого типа является часто встречаемое замутнение кристаллов. При этом, замутненной может быть середина кристалла, при том, что краевые части остаются прозрачными или, напротив, - замутненными и полупрозрачными являются краевые части кристаллов, тогда как их центральные части остаются прозрачными. Торпедовидный морфологический тип образован прозрачными бесцветными или бледноокрашенными в желтовато розоватые тона цирконами призматического габитуса. Размер кристаллов 100-450 мкм, коэффициент удлинения 3-5. Облик кристаллов, обусловленный развитием граней (100), (110), (113), идиоморфный. В площадном отношении явно преобладают грани призматического пояса. Поверхность граней часто трещиноватая. Внутреннее строение кристаллов многозональное. Расположение зон относительно друг, как правило, симметричное. Отмечаются ядра округлой и удлиненной формы (рис. 3.21-3.23). Среди включений обнаружены кварц, эпидот, апатит, расположенные хаотично. Циртолитовый морфологический тип представлен призматическими и длиннопризматическими кристаллами буровато желтого или коричневого цвета непрозрачными, слегка уплощенной формы. Размер кристаллов 150650 мкм, коэффициент удлинения 3-5. Облик кристаллов, обусловленный развитием граней (100), (110), (113), (112), идиоморфный. Поверхность граней трещиноватая, рельеф неровный. Внутреннее строение кристаллов характеризуется наличием ядер округлой и удлиненной формы, реже они имеют геометрические очертания (рис. 3.24-3.25). Среди включений часто отмечаются торит, ураноторит, титанит реже апатит и кварц. Детритовый морфологический тип представлен окатанными зернами циркона, в которых первичные морфологические особенности кристаллов утрачены.

Распределение морфотипов цирконов в гранитах разных массивов, и их количественные соотношения показаны в таблице.

Таблица

Распределение морфологических типов цииконов в гранитных массивах северной части Приполярного Урала

\begin{tabular}{|l|c|c|c|c|c|c|}
\hline \multirow{2}{*}{ Массив } & \multicolumn{7}{|c|}{ Морфологические типы цирконов, (\%) } \\
\cline { 2 - 7 } & $\begin{array}{c}\text { Детри- } \\
\text { товый }\end{array}$ & $\begin{array}{c}\text { Цирко- } \\
\text { новый }\end{array}$ & $\begin{array}{c}\text { Гиацин- } \\
\text { товый }\end{array}$ & $\begin{array}{c}\text { Копье- } \\
\text { видный }\end{array}$ & $\begin{array}{c}\text { Торпедо- } \\
\text { видный }\end{array}$ & $\begin{array}{c}\text { Циртоли- } \\
\text { товый }\end{array}$ \\
\hline Николайшорский & ед. зерна & - & 40 & 50 & 10 & - \\
\hline Кожимский & - & 80 & - & - & 5 & 15 \\
\hline Бадьяюский & - & 70 & 15 & - & 5 & - \\
\hline Яротский & - & 50 & 45 & - & 10 & - \\
\hline
\end{tabular}


Из данных, приведенных в таблице видно, что максимальное количество морфотипов цирконов (четыре) присутствует в гранитах Николайшорского массива. Преобладающими являются цирконы копьевидного типа, отмеченные только в породах этого массива и составляющие до $50 \%$ от общего количества минерала в пробе. Наличие в породах копьевидных цирконов обусловлено глубинными условиями становления гранитоидов, характеризующихся широким развитием пегматитов и мигматитовых ореолов [25]. Кроме того, граниты Николайшорского массива отличаются от всех других присутствием детритовых цирконов и отсутствием цирконов раннемагматической генерации (цирконового морфотипа). Отсутствие цирконов раннемагматической генерации может быть связано с неоднократным проявлением процессов ремобилизации гранитов и, соответственно, регенерации ранее образованных акцессорных минералов. То, что циркон цирконового морфотипа ранее мог присутствовать в николайшорских гранитах, доказывается установленными фактами обрастания короткопризматических кристаллов цирконов (цирконового морфотипа) дипирамидально-призматическими копьевидными (рис.3.18, 3.20).

Кожимский, Бадьяюский и Яротский гранитные массивы по условиям становления относятся к малоглубинным образованиям. Вероятно, это является одной из причин отсутствия в них цирконов копьевидного типа. В гранитах Кожимского массива, в отличие от Бадьяюского и Яротского, присутствуют цирконы циртолитового морфотипа, что является признаком метасоматической (или метаморфической) переработки пород [26]. Учитывая, что кожимские граниты, слагающие пластообразное тело в нижней части разреза пуйвинской свиты $\left(\mathrm{RF}_{2-3}\right)$, имеют «пуйвинский» возраст, они действительно были метаморфизованы совместно с вмещающими породами [27], что подтверждается петрографическими исследованиями. Присутствие практически во всех зернах цирконов, относящихся к цирконовому типу, регенерационных каемок (рис.3.14), вероятно, также связано с ремобилизацией гранитов при наложенном метаморфизме.

Бадьяюские и яротские граниты имеют аналогичный набор морфотипов циркона, которые в сравнение с николайшорскими и кожимскими гранитами характеризуются наиболее простыми формами этого минерала, что свойственно однофазным массивам [28].

\section{Заключение}

Теоретические, экспериментальные и эмпирические данные по морфологии цирконов свидетельствуют, что в форме кристаллов этого минерала заложены важные сведения об условиях кристаллизации вмещающих его пород.

При всем морфологическом многообразии, сложности внутреннего строения и состава циркона в метаморфических породах существуют определенные закономерности, позволяющие выделить типоморфные признаки этого минерала, связанные с условиями породообразования. Так, эмпирически установленная приуроченность округленных цирконов к породам гранулитовой и эклогитовой фаций позволяет считать цирконы округленной формы (типа «футбольного мяча») показателем экстремальных (ультравысокотемпературных и ультравысокобарических) условий метаморфизма. Призматические цирконы «мигматитового» типа, являясь фактически магматическими минералами, указывают на проявление в породах процессов частичного плавления. Наличие в метаморфических образованиях цирконовых агрегатов сложной формы (типа «цветной капусты»), скорее всего, свидетельствует об относительно низкотемпературных условиях изменения пород, не превышающих низких ступеней амфиболитовой фации. Лишь в метаморфитах основного ряда, имеющих в сравнении с породами кислого состава более высокий температурный порог мигматизации, цирконы типа «цветной капусты» сохраняются в более высокотемпературных условиях.

Цирконы из пород разных гранитоидных комплексов, занимающих разную геологическую позицию и различающихся по изотопному возрасту, отличаются по набору морфотипов и их количественным соотношениям. Так, наличие в гранитах копьевидных цирконов указывает на глубинные условия становления пород. Циркон циртолитового типа может являться признаком метасоматической (или метаморфической) переработки гранитов. Наиболее простые формы цирконов характерны для однофазных гранитных массивов, более сложные - для многофазных и полифациальных массивов, а также гранитов, испытавших метаморфические и метасоматические преобразования.

Исследования проведены в рамках НИР ИГ Коми НЦ УрО РАН ГР № АААА-А17-117121270035-0 и при финансовой поддержке Программы фундаментальных исследований РАН № 18-5-5-19.

\section{ЛИТЕРАТУРА}

1. Woensdregt, C.F. Computation of Surface Energies in an Electrostatic Point Charge Model: I. Theory / C. F. Woensdregt // Phys. Chem. Minerals. - 1992. -V. 19. - P. 52-58..

2. Woensdregt, C. F. Computation of Surface Energies in an Electrostatic Point Charge Model:II. Application to Zircon (ZrSi04) / C. F. Woensdregt // Phys. Chem. Minerals. - 1992. V. 19. - P. 59-69.

3. Caruba, R. Crystal growth of synthetic zircon round natural seeds / R. Caruba, A. Baumer, P. Hartman // J. Crystal. Growth. 1988. 88. P. $297-302$.

4. Vavra, G. Systematics of internal zircon morphology in major Variscan granitoid types / G. Vavra // Contrib. Mineral. Petrol. 1994. - V. 117. - P. 331-344.

5. Pupin J.P. Zircon and granite petrology / J. P. Pupin // Contrib. Miner. Petrol. - 1980. - V. 73. - P.207-220.

6. Vavra, G. Guide to quantitative morphology of zircon / G. Vavra // Chem. Geology. - 1993. - V.110. - C. 15-28.

7. Benishek, A. Factors controlling the development of prism faces in granite zircons: a microprobe study / A. Benishek, F. Finger / Contrib. Miner. Petrol. - 1993. - V.114. - P. 441-451. 8. Atlas of Zircon Textures. / Fernando Corfu [et al.] // In Honchar J.M., Hoskin P.W.O. (eds) Zircon. Reviews in Mineralogy 
\& Geochemistry. - 2003. - V.53. - P. 469-495.

9. Huneke, J. C. Zircons of Summit Rock / J. C. Huneke, G. R. Rossman // Oregon. Mineral. Record. - 1978. - P. 392-393.

10. Poldervaart, A. Zircon in Rocks. 2. Igneous rocks / A. Poldervaart // Amer. J. Sci. - 1956. - V.254. - P.521-554.

11. Scoates, J. S. Baddeleyite $\left(\mathrm{ZrO}_{2}\right)$ and zircon $\left(\mathrm{ZrSiO}_{4}\right)$ from anortositics rocks of the Laramie anorthosite complex, Wyoming:Petrologic consequences and U-Pb ages / J. S. Scoates, K. R. Chamberlain // Amer. Mineral. - 1995. - V.80. - P. 1317-1327.

12. Growth, annealing and recrystlisation of zircon and preservation of monazite in high-grade metamorphism: conventional and in-situ U-Pb isotope, cathodoluminescence and microchimical evidence. / U. Schaltegger [et al.] // Contrib Mineral Petrol. - 1999. - V. 134. - P. 186-201.

13. Geohemical and Geochronological cross-section of the deep Variscan crust: The Cabo Ortegal high-pressure nappe (northwestern Spain) / J. J. Peucat [et al.]// Tectonophusics. - 1990. V.110. - P. 463-472.

14. Носырев, И. В. Основные черты онтогении акцессорного циркона метаморфических пород / И. В. Носырев // Циркон в породах докембрия и фанерозоя. М.: Наука, 1985. - С.1525.

15. Носырев, И. В. Анатомия кристаллов акцессорного циркона и эволюция минералобразующей среды / И. В. Носырев // Типоморфизм, синтез и использование цирконов. Киев: Наукова думка, 1989. - С.37-47.

16. Бибикова, E. В. Геохронологическое датирование метаморфических процессов по циркону / Е. В. Бибикова, Т. В. Грачева, Т. И. Кирнозова // Геологические исследования докембрия на основании изучения акцессорных минералов. М. Наука, 1985. - С.15-30.

17. Atlas of zircon textures / F. Corfu [et al.] // Reviews in mineralogy and geochemistry. -2003 . -V 53. - P.469-500.

18. Пыстин, А. М. Базальные отложения верхнего докембрия в Тимано-Североуральском регионе / А. М. Пыстин, Ю. И. Пыстина // Литосфера. - 2014. - № 3. - С.41-50.

19. Пыстина, Ю. И. Морфологические особенности цирконов, как критерий физико-химических условий метаморфизма (на примере гнейсовых комплексов Урала) / Ю. И. Пыс- тина, А. М. Пыстин, И. Л. Потапов // Связь поверхностных структур земной коры с глубинными. Материалы 14-ой Международной конференции. Часть 2. Петрозаводск: Карельский НЦ РАН, 2008. С. 138-139.

20. Pystin, A. The early Precambrian history of rock metamorphism in the Urals segment of crust / A. Pystin, J. Pystina // International Geology Review. - 2015. - V.57. - P. 1650-1659. 21. Раннедокембрийская история метаморфизма пород гранулитовых и эклогитовых комплексов палеоконтинентальной зоны Урала. / А. М. Пыстин [и др.] // Сыктывкар: Геопринт, 2012 - 46 c.

22. Краснобаев, А. А. Циркон как индикатор геологических процессов / А. А. Краснобаев // М.: Наука, 1986. - 152 с.

23. Пыстин, А. М. Новые данные о возрасте гранитоидов Приполярного Урала в связи с проблемой выделения кожимской среднерифейской гранит-риолитовой формации / А. М. Пыстин, Ю. И. Пыстина // Известия Коми НЦ УрО РАН, Сыктывкар. - 2011. - вып. 4. - С.73-78.

24. Пыстин, А. М. Метаморфизм и гранитообразование в протерозойско-раннепалеозойской истории формирования Приполярноуральского сегмента земной коры / А. М. Пыстин, Ю. И. Пыстина // Литосфера. - 2008. - № 8. - С. 25-38.

25. Пыстина, Ю. И. Типоморфные признаки цирконов как критерий для расчленения и корреляции гранитоидов (на примере северной части Приполярного Урала) / Ю. И. Пыстина, Ю. В. Денисова, А. М. Пыстин // Вестник Института геологии Коми НЦ УрО РАН. - 2017. - №12.- С. 3-15.

26. Фишман, М. В. Минералогия, типоморфизм и генезис акцессорных минералов изверженных пород севера Урала и Тимана. / М. В. Фишман [и др.] // Л.: Наука, 1968. - 250 с.

27. Пыстин, А. М. Карта метаморфизма Приполярного и южной части Полярного Урала. / А. М. Пыстин // Научные доклады. Коми научный центр УрО АН СССР. - 1991. Вып. 259. -20 c.

28. Зинченко, О. В. О двух концепциях эволюции морфологии акцессорного циркона / О.В. Зинченко, В.Ф. Гринченко // Типоморфизм, синтез и использование циркона. Киев: Наукова думка, 1989. - С.20-24.

Institute of Geology, RAS Ural Branch, Syktyvkar

Pystina Yu. I., Doctor of Geological and Mineralogical Sciences, Leading Researcher, Professor

E-mail:yuliya_pystina@mail.ru

Тел.: 89042031020

Pystin A. M., Doctor of Geological and Mineralogical Sciences, Leading Researcher, Professor E-mail:pystin@geo.komisc.ru Tel.: 89087171938 